\title{
INCLUZIUNEA SOCIALĂ A RROMILOR ÎN SERBIA. IMPLEMENTAREA MODELULUI ROMÂNESC ÎN TREI MUNICIPALITĂȚI (FOCUS PE PROGRAMUL DE SĂNĂTATE)
}

\section{Ghinescu Minerva Claudia'}

${ }_{3}^{1}$ sef lucrări, doctor în medicină, medic primar medicină de familie, Universitatea "Titu Maiorescu“, Bucureşti, Facultatea de Medicină, consultant internațional UNFPA

\author{
Adresa de corespondență: \\ Ghinescu Minerva Claudia, MD, FP, PhD \\ Buftea, aleea Școlii nr 2-4, județul Ilfov, cod 70000 \\ email:ghinescu_minerva@yahoo.com
}

Title: Inclusion of Roma in the Society in Serbia. Implementation of Romanian Model in three Municipalities (focus on Health Programme)

\section{Abstract}

This report describes the assessment of the potential in the three municipalities to start the implementation of community based health programs. It also describes the possibility of strengthening the capacity of Roma health mediators, other medical personnel and stakeholders in the local authorities to improve the access of Roma ethnics to quality medical services and to improve their general health status.

An important observation is that availability and accessibility of quality health care is an issue for all Serbians, not just for Roma. The national health system ensures universal access to primary and specialised medical services. Identification papers and health ID are necessary. Local Health Care Centres in three municipalities have their contribution to deliver to the improvement of quality of care in general.

UNFPA Country Office in Serbia collaborates with the Ministry of Labor and Social Politics and the Roma Secretariat within the Agency for Human and Minority Rights responsible for Roma Decade implementation.

The objective of the present project, supported by the Romanian Government, is to develop a model of Roma integration (Romanian model - Buftea) and implement it in three pilot municipalities: Smederevo, Beocin, Prokuplje.

Key Words: UNFPA Country Office in Serbia, accessibility of quality health, assessment, roma health mediator, stakeholders, Smederevo, Beocin, Prokuplje, Local Health Care Centres, Roma Decade.

\section{Rezumat}

Acest raport descrie evaluarea potențialului din trei municipalitați din Serbia în ceea ce privește începerea implementării de programe comunitare de sănătate. De asemenea descrie posibilitatea consolidării capacitații sistemului de sanătate, inclusiv al mediatorilor sanitari rromi împreună cu alt personal medical și alți responsabili din cadrul autoritaților locale de a îmbunătați accesul populației rrome la servicii medicale și starea lor de sănătate. 
O observație importantă este că disponibilitatea și accesibilitatea îngrijirilor medicale de calitate este o problemă pentru toți sârbii, nu doar cei din populația rromă. Sistemul național de sănătate asigură acces universal la îngrijiri medicale primare şi de specialitate. Actele de identitate şi carnetele de sănătate sunt necesare. Centrele de sănătate locale din cele trei municipalitați contribuie la îmbunătățirea calității îngrijirilor în general.

UNFPA Serbia colaborează cu Ministerul Muncii şi al Politicilor Sociale, dar şi cu Secretariatul Minorității Rrome din cadrul Agenției pentru Drepturile Omului şi Minorităţilor, responsabil cu implementarea Decadei Rrome.

Obiectivul acestui proiect, susținut de Guvernul României, este de a crea un model al integrării populației rrome similar proiectului pilot din Romania (Buftea) şi de a-l implementa în trei municipalitați-pilot: Smederevo, Beocin, Prokuplje.

Cuvinte cheie: UNFPA Serbia, evaluare, acces, calitatea serviciilor medicale, etnie rromă, mediatori sanitari rromi, parteneriat, Smederevo, Beocin, Prokuplje, centru de asistență medicală primară, Decada Roma.

This report provides an assessment of current situation in three municipalities (Smederevo, Beocin and Procuplje) about the access to health services of the Roma population and the potential in the three municipalities to start the implementation of community based health programs, how to strengthen the capacity of existing RHM, what are the stakeholders to be involved and the capacities and resources required.

The needs assessment mission was conducted at the request of the UNFPA Country Office in Serbia under the SRB0P12A project financed by the Government of Romania. The main objective of the mission was to assess the possibilities to implement community based health programmes in the selected municipalities.

As a clarification of the terms of reference, it was agreed that no data on health status of the Roma should be collected during the mission. Currently available information allows for sufficient conclusions and measures, as this report will demonstrate. In particular situations, however, the availability of specific health related information of the Roma population may help to define targeted policies and interventions.

Generally speaking, health of people is more related to their living conditions than to their health care. Also, it is common knowledge that health of many communities is negatively related, to a large degree, to low income, low education levels and unhygienic living conditions, which result from social exclusion and isolation.

The status of this report is as follows. The findings described in the assessment represent the information and analyses collected by the mission team and the responsibility of the team.

\subsection{Methology of work, purpose and scope of the report}

In line with the Terms of Reference, a team of 2 International Consultants compiled this report: Dr. Minerva Ghinescu and Ms. Mariana Buceanu. Both have previous working experience in Romania, one of them is a doctor with public health background, and one is specialized in social work. Both have working experience - in other countries and Romania - with Roma population or with the topic at hand: access to health and social services of Roma, development and implementation of Roma integration programs.

The assignment requires thorough information on past and current policies.

Therefore, in the first phase of the project, the team concentrated on reading existing documentation i.e. "Consultancy Report" by Ivana Koprivica (document created at the request of the UNFPA Country Office in Serbia, Report of Study Visit in Serbia (2008); the "Decade of Inclusion”; "Strategy, the antidiscrimination law".

During the second phase, the two consultants together with the UNFPA Programme Officer have visited three different regions in the country: 
1. Smederevo -Central Serbia (15-16 June 2009)

2. Beocin - North of Serbia-Voievodina Province (17 June 2009)

3. Procuplje - South of Serbia ( 17-18 June 2009)

In the municipalities the team contacted a variety of stakeholders.

During the visits, semi-structured interview techniques were used. The fields of interest were the following:

Issues of functioning, quality of and access to health services in general; this included subjects like: these same issues, but especially for Roma population and communities; this involves subjects like the Roma Health Mediator and Home Nursing, responsibilities in terms of policy and management of the health system, the number of RHM, HN, GP, distance to Local Health Care Centre, communication with Roma population, knowledge about Roma culture and behaviour, role and contributions of Roma coordinators and NGOs to special projects.

In each municipality, the following stakeholders have been contacted: municipality representative, mayor, Roma Coordinators for Roma issues, members of the municipal council responsible for health-related and social infrastructures.

Also some Roma communities were visited. Contact was made with the staff of the local Health Centre, Centre for Social Work, Local Employment service, local Roma leaders and several Roma NGOs. Several Roma districts in the municipalities were visited as well (Smederevo - Kvala Mala, Beocin - Sljivik, Procuplje-Cerkez Mala).

After these visits the team compiled and discussed the information collected. For clarification, a number of the resource persons or instances were contacted again. This way, elaborate triangulation of the information was done.

The activities of the team and the project were discussed with the UNFPA Programme Officer in Serbia. During the meeting, the draft Action Plan was discussed to some extent.

The mission was implemented according to Terms of Reference. All conclusions are those of the authors.

\section{Current context and policies}

\subsection{General}

An important part of this assessment concerns the context that is relevant to Roma community health needs, with special focus on access to health care of Roma. We distinguish two elements: firstly, policies, practices and organizations in relation to the situation of Roma, both in and outside Serbia; secondly, policies and practices related to health and social care, local authority and Roma leaders in the three municipalities - Smederevo, Beocin and Procuplje.

These elements define the opportunities and constraints in which the Action Plan will find its place. Therefore, we describe both. At the end of the chapter we draw some conclusions, which underlie the Action Plan.

\subsection{International - roma decade and council of europe}

The initiative "Decade of Roma Inclusion" was adopted by eight countries: Serbia, Bulgaria, Croatia, the Czech Republic, Hungary, Macedonia, Romania, Montenegro and Slovakia and it is supported by the international community. It represents the first cooperative effort to change the lives of Roma in Europe. The Decade is an action framework for governments that runs from 2005-2015. The objectives of the initiative are to improve and to monitor the progress in accelerating their social inclusion.

The Government of Serbia developed and adopted the National Action Plan for Roma Decade with 4 priority areas: Education, Employment, Health and Housing and Environment, and commits governments to take into account the other core issues of poverty, discrimination and gender mainstreaming. 
As part of the "Decade of Roma Inclusion" (2005-2015), a Europe-wide effort coordinated by international organizations including the United Nations Development Program, the World Bank, and the Council of Europe, the Serbian government has initiated a number of pilot programs to help Roma families become registered; gain access to health care, education, job training, and employment opportunities; and obtain adequate housing. However, the scale of such efforts has been relatively small, and implementation has often been thwarted by widespread prejudice against Roma. In general, Serbian authorities acknowledge the need for action, but Roma advocates and international observers say that up to this point there has been little impact on the community.

Goals for the Health area are: the implementation of health programs in all Roma communities with special focus on preventive programs, health promotion; the guarantee of access to medical services for all Roma (the Roma Health Mediator program has been implemented since its creation in June 2008 - the Model of Romania), increase of their health knowledge, increase of health education in Roma communities.

According to the European Committee (November 2004) the situation of Roma ethnics regarding general health condition can be concluded: poverty, precarious living conditions, lack of health education, lack of information about health laws, rights and obligations they confer, along with discrimination determine reduced access to medical services, high morbidity (infectious diseases: TBV and viral hepatitis), and low health expectancy.

\section{Detailed analysis of the situation in the municipalities (smederevo, beocin and prokuplje)}

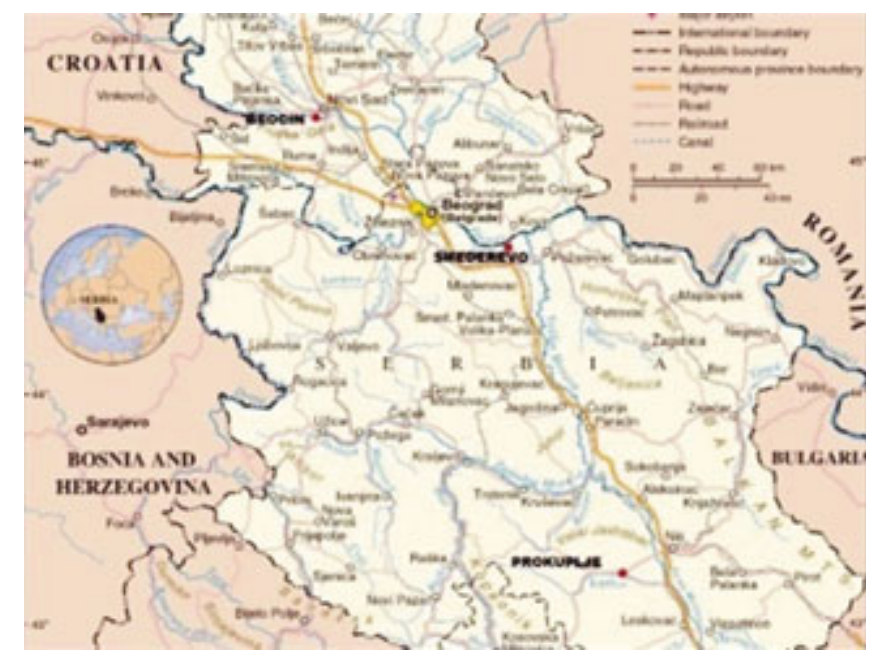

\subsection{Basic information}

The town of Smederevo is located in Central Serbia, and belongs to the Podunavski district. The town of Smederevo covers an area of 481 sqKm, with 27 settlements (one urban, seven suburban and nineteen rural) and has 109.809 inhabitants (the census from 2002) of which 1801 are Roma. However, the exact number of Roma is much higher. According to Roma NGOs there are around 8,000 Roma, while according to the Strategy for the Development of Social Welfare (2008-2012) there are 20.000 Roma. There are 9 Roma settlements in Smederevo.

The largest Roma settlement is Mali Kriva with over 2,000 inhabitants. Many Roma families live in these illegal settlements that lack basic infrastructure, including running water, sewers and electricity (although many households connect to the power grid with hazardous homemade wiring). Living in unregistered housing constitutes a significant obstacle to the acquisition of identity documents, which contributes to what Roma advocates describe as a vicious circle for these families. Lacking identity papers, they are unable to find formal work or enrol their children in the education system that will train them for more promising employment opportunities; therefore subsisting on the work they can 
find recycling scrap material, they must live in illegal, unsanitary housing conditions; living in unregistered housing, it is difficult to obtain identity documents.

Beocin is located in Voievodina, in the Juznobacki district, $17 \mathrm{Km}$ from Novi Sad. The administrative centre and largest settlement of the municipality is Beocin and the population of the municipality is 16,398 . More than half of the total population lives in the town of Beocin, making it the largest settlement.

Beocin is a multiethnic environment. According to the official census from 2002 the Roma are the second largest group (6,51\%), numbering 1019 according to official information. However, unofficial estimates indicate that the number ranges from 1600-1700 Roma; $10 \%$ live in the municipality of Beocin, mostly concentrated in the Roma settlements Sljivik and Kolonije.

There are a large number of internally displaced persons in the municipality of Beocin, especially those who moved there after 1999. Most of the internally displaced Roma living in Beocin are of the Muslim religion.

The Municipality of Prokuplje is located in the south of Serbia, in the Toplica district. The municipality of Prokuplje is very large in terms of area and includes, in addition to the town of Procuplje, another 106 inhabited areas. It is divided into 92 local communities. 48,501 people live in Prokuplje according to data from the official census from 2002. According to the same source, in the municipality of Prokuplje there are 3-7 \% inhabitants of Roma ethnicity.

According to data from the Strategy for Sustainable Development of the Municipality of Prokuplje, it is estimated that there are actually many more Roma and that the total number of Roma citizens in the municipality exceeds 5\%; according to other unofficial indicators, that number is much higher, about $10,5 \%$. According to data from the Municipal Health Centre, $9.7 \%$ of the total number of children of school age are Roma.

Roma live predominantly in the town, concentrated in two communities: Cerkez Mala and Carina. They mainly live in extended families, have no working qualification and are unemployed.

A large number of families are oriented towards the assistance and protection of the Centre for Social Work. A large number of Roma families are included in the program for social welfare (792 families with a total 2,150 members (data from the Strategy for Sustainable Development of the Municipality).

\subsection{Health status of roma}

The area of health is very important among the Roma population in Smederevo, Beocin and Prokuplje, given the Roma population numbers and the problems they face, as well as the very poor housing and hygienic conditions in Roma settlements.

The municipal Health Centre "St. Luka Health Centre" (Smedevo), ensures medical care for all inhabitants of Smederevo, whether they are Roma or not (primary and specialty health care is provided). As part of the municipal health centre, there is a service for the improvement of health and for multi-role home visits which function in these areas and health education.

Analyzing interviews shows that Roma ethnics in Smederevo are not confronted with health problems that are essentially different to those of the majority population. Interviewed health specialists identified certain specific health issues deriving from poverty and the culture of poverty: respiratory pathology is predominant followed by digestive pathology, dental afflictions, all deriving from precarious living conditions and bad hygiene.

The municipality of Prokuplje is more at risk among the areas of Serbia in terms of health care. Awareness of the population concerning health care is low. Adherence to tradition is very present in this region and the importance of family is great, with the patriarchal tradition very much in evidence. Some social groups, including Roma, are particularly exposed to poverty in the municipality of Prokuplje. The poorest families live in the village and Roma settlements. The characteristic of settlements in which the Roma live are: unplanned infrastructure, lack of sanitation, poor public 
utilities and a lack of official electrical network installations. The vicious circle of poverty in which most of the Roma population lives continues to perpetuate a lack of education.

There is a high percentage of juvenile pregnancy in the Roma population (according to data from the Toplica Health Center-2005).

Only $5.2 \%$ of Roma women receive any information about HIV/AIDS during pregnancy checkups. More than $6 \%$ of women who were included in this survey gave birth outside the hospital. There is an increase in the birth rate of children with congenital defects.

There is very high percentage of children born with low body weight (under 2,500 $\mathrm{g}$ ) in the Roma population.

A series of problems are determined by a lack of organizing one's life in terms of family planning. In traditional Roma communities, fertility is not controlled.

Interviewed Roma leaders complete the image of the quality of life in the case of Roma ethnics, placing a deficit of education in this vicious circle.

The life conditions of Roma communities are determined not only by being part of a marginal social category (lack of access to public utilities) but also by the way the resources they have are used "...bad hygiene, agglomeration in living spaces are factors that depend on the level of culture and individual effort...".

The causes of the incidence of specific pathology are related to the culture of poverty and poverty in itself.

Interviewed Roma coordinators put the practice of child labour from an age of 9-10 into the sphere of the culture of poverty. This practice determines illiteracy and school abandonment.

The interviewed subjects underlined the fact that in the case of Roma children, there are not any specific diseases different from those of children from the majority population.

Interviewed specialists identified the following problem-areas in terms of health regarding children from Roma communities: respiratory diseases (bronchiolites, broncho-pneumonias), digestive diseases (enterocolites and parasitoses), anemia, rachitism, and dermatological afflictions.

The main causes of disease in the case of Roma children refer to socio-economic conditions and parental negligence, a symptom of the culture of poverty. Specialists consider that inadequate eating conditions, the lack of alimentary hygiene, bad alimentation, lack of means of subsistence, all have a direct impact on the health of Roma children.

Some interviewed Roma ethnics invoke discrimination and negative reactions towards doctors, while medical personnel invoke the chronic negligence of Roma ethnics towards elementary hygiene, prescribed prevention conditions and advice.

The causes of these specific health problems are considered by the interviewed subjects as being the same: precarious socio-economic conditions and the culture of poverty sustaining them. Interviewed health specialists are under the opinion that the reduced level of education in the case of Roma women limits their access to information and determines precarious eating conditions, insalubrious living spaces and bad hygiene along with a negligent attitude based on a traditionalist culture.

\subsection{Health care accessibility}

\subsubsection{Access to general practioners, hospitals and medical specialists}

The team and the managers of St. Luka Health Centre (Smederevo), the Toplica Health Centre (Prokuplje Municipal Health Centre) and Municipal Health Centre of Beocin discussed their views on accessibility and care for Roma patients.

Also, the team visited three Roma settlements and had contact with the Roma people.

One obvious observation is the variety of settings in which their Roma patients live and variety of cultural and individual characteristics. The doctors acknowledge the need for improvement of 
health care and accessibility to health care for Roma patients and are willing to invest themselves in their professional relationship.

The doctors would appreciate support in their contact with Roma patients. They need skills and practical tools to improve communication.

Another obstacle in accessing health care is the need for identity documents, which many Roma do not possess. Existing regulations to obtain identity documents in principal are transparent, but many Roma are not able to take the necessary steps, because of the bureaucratic application of procedures. In Smederevo there are initiatives and projects including the RHM, which provide help in obtaining the documents.

Because of the lack of identity documents and health insurance, many people, especially Roma, present themselves in a late stage of disease, and outside office hours.

We did not attempt to quantify in any way discriminatory attitudes.

Concerning informal exclusion (opinion of NGO representatives) of Roma ethnics from medical services, there are two categories of factors that could be identified:

a. General factors concerning the organizing and functioning of the medical assistance system: formal and informal costs, the quality of medical services, the disproportionate distribution of hospital and ambulance units which offer services due to geographic and residential positioning, specialized services which do not exist in rural areas, the imbalance between the curative and preventive parts, bureaucratic and administrative problems concerning the relation to the patient or the medical act, overpopulated lists, the lack of informing among patients, diminished real consult time, the small number of nurses, the lack of logistics and infrastructure necessary for family planning services, the absence of pharmacies in the studied communities.

b. Specific factors concerning discrimination: the interviews with direct beneficiaries revealed a series of attitudes (positive and negative) of Roma patients towards doctors in general.

\section{Conclusions}

1. The Ministry of Health has been among the more active Ministries in terms of policy development to improve the health of Roma. However, the support to the development of the RHM is the only activity implemented - next to the initiation of this project. Important though the RHM may be, there is a need to develop many other activities.

2. Many doctors, nurses, hospital staff in the 3 municipalities are interested in learning to improve their communication with Roma patients.

3. Representatives of local institutions in the three municipalities (the Health Centre, the Centre for Social Work, the municipalities etc.) are not familiar with the culture and traditions of the Roma people, and there is obvious stereotypical thinking, prejudice and discrimination towards Roma. They would benefit from information and counselling on intercultural communication and from practical information with regards to the Roma situation.

4. In the three municipalities very few health data specific for Roma have been collected. For calculating the incidence and prevalence of diseases, it would be particularly useful to gather data from each community in order to develop specific preventive and curative actions in the future (epidemiological survey).

5. All three of the municipalities that were included in the visit (Smederevo, Beocin, Prokuplje) were open to cooperation and motivated towards adopting the Romanian model and experience.

6. The stakeholders who are dealing with Roma health in all three municipalities (the Municipalities, the Health Centre, the Centre for Social Work, the Roma NGOs, the coordinator for Roma issues) are ready to get involved in developing a network of support at a local level and are ready to get involved in training programs regarding Roma issues. 
7. Home-visiting services exist in all three municipalities, which are of varying scope and levels of development. The Roma Mediators are placed with the home-visiting service as soon as they "enter" the health system.

8. All three municipalities have Roma coordinators who are interested in the development and implementation of the activities of the Local Action Plan for Roma in the area of health. The experiences of the Roma coordinators from all three municipalities regarding the Romanian model - involvement of Health mediators in medical services - are positive and it would be usefully applied in the specific context of the three municipalities.

9. The Health Mediators, Home-visiting nurses, doctors and Roma coordinators for Roma issues could be included in training for building professional capacities in accordance with the requirements of the job description. 